\title{
Freezing Resistance of Progeny from Open-pollinated Pummelo $\times$ Trifoliate Orange Citrus Hybrids
}

\section{G. Yelenosky, D. Hutchison', and H. Barrett \\ U.S. Department of Agriculture, Agricultural Research Service, Horticultural Research Laboratory, 2120 Camden Road, Orlando, FL 32803}

Additional index words. citrus germplasm, cold acclimation, controlled environment, leaf morphology

\begin{abstract}
Ten-month-old seedlings, grown from seed extracted from 22 individual pummelo [Citrus grandis (L.) Osbeck] $\times$ trifoliate orange [Poncirus trifoliata (L.) Raf.] citrus hybrid trees that survived $\mathbf{- 1 5 C}$ freezes near Monticello, Fla., were cold-acclimated in controlled-environment rooms and freeze-tested at $-6.7 \mathrm{C}$ for $4 \mathrm{~h}$. Freeze damage to open-pollinated progeny was ranked by the number of uninjured seedlings and percentage of leaves killed and wood dieback. Morphological segregation was not associated with differences in freeze survival, and the dominant trifoliate gene was readily evident. Progeny from one tree, identified as 98-71, are considered the most likely candidates for further study in developing cold-hardy citrus trees.
\end{abstract}

In continuing searches for cold-hardy citrus types in Florida to support genetic initiatives in citrus freeze survival, open-pollinated seedling progeny from twenty-two 15 -yearold pummelo $x$ trifoliate orange citrus hybrid trees were screened for cold hardiness. [Original cross was made by A.P. Pieringer (retired), Univ. of Florida, Institute of Food and Agricultural Sciences, Lake Alfred.] Trees consistently survived severe freezes without visible injury when grown near Monticello, Fla., which is in hardiness zone 8 [-6.6 to $-12.3 \mathrm{C}$ average annual minimum; U.S. Dept. of Agriculture (USDA) Plant Hardiness Zone Map]. On site, temperatures were as low as $-15.6 \mathrm{C}$ in Jan. 1985 (P.C. Anderson, personal communication). Pummelo often expresses a high ratio of zygotic progeny, hybrid vigor, and fruitfulness with few unfavorable traits (Cameron and Soost, 1974). These characteristics complement the superior cold hardiness of Poncirus, which has a dominant trifoliate leaf gene. In a numerical taxonomic study of affinity relationships, pummelo is considered a true biological species, and trifoliate orange is connected to Citrus through $C$. aurantium L., an apomictically perpetuated biotype of hybrid origin (Barrett and Rhodes, 1976). Open-pollinated pummelo $\times$ trifoliate orange progeny have not been screened for freeze survival potential.

Seedlings were grown from seed extracted from 22 individual hybrid trees at Monticello,

\footnotetext{
Received for publication 8 Mar. 1993. Accepted for publication 8 July 1993. Mention of a trademark, warranty, proprietary product, or vendor does not constitute a guarantee by the U.S. Dept. of Agriculture and does not imply its approval to the exclusion of other products or vendors that may also be suitable. The cost of publishing this paper was defrayed in part by the payment of page charges. Under postal regulations, this paper therefore must be hereby marked advertisement solely to indicate this fact. 'Retired.
}

and each tree lot was germinated in peat/ vermiculite in separate trays under greenhouse conditions. Polyembryonic seed were suspect in five of the 22 tree seed lots that are identified in Table 1. Presumed nucellar seedlings (based on leaf morphology) were excluded from freeze survival performance. Three-month-old seedfoliate groups based on leaf morphology to lings in each tray were separated into different

${ }^{2}$ Freeze defined as $-6.7 \mathrm{C}$ for $4 \mathrm{~h}$. determine if differences in leaf morphology were associated with freeze performance of zygotic seedlings. There is no evidence to suggest such an association, which apparently has not been addressed in citrus cold-hardiness studies. Seedlings were transplanted to 3-liter plastic pots (one per pot) containing "ProMix" [shredded sphagnum peat with equal parts of vermiculite and perlite with macroand micronutrients added (Premier Brands, New Rochelle, N.Y.)]. Seedlings were maintained in a shaded greenhouse under natural daylight at $1000 \mu \mathrm{mol} \cdot \mathrm{m}^{-2} \cdot \mathrm{s}^{-1}$ maximum photosynthetic photon flux (PPF). The air ranged from $32 \mathrm{C}$ day maximums to $15 \mathrm{C}$ night minimums, and relative humidity $(\mathrm{RH})$ ranged from $35 \%$ day lows to $99 \%$ night highs. Seedlings were watered every 2 days and fertilized monthly with $250 \mathrm{ml}$ of $12 \mathrm{~N}-2.6 \mathrm{P}-5 \mathrm{~K}$ that included micronutrients.

Seedlings, $\approx 10$ months old, were coldacclimated by consecutively cooler day/night temperatures in controlled-environment rooms described by-Yelenosky (1979). Cold-hardening conditions were $21 \mathrm{C}, 12-\mathrm{h}$ day (500 $\left.\mu \mathrm{mol} \cdot \mathrm{m}^{-2} \cdot \mathrm{s}^{-1} \mathrm{PPF}\right), 10 \mathrm{C}$ night, and $50 \% \pm 5 \%$ RH for 2 weeks immediately followed by 2 weeks of $15 \mathrm{C}$ days and $4 \mathrm{C}$ nights. Freeze tests, which immediately followed 4 weeks of cold acclimation, were done in darkness in a separate room adjacent to acclimation rooms. Freeze tests included 1-h equilibration at $2 \mathrm{C}$ followed by a $1 \mathrm{C} / \mathrm{h}$ decrease to $-6.7 \mathrm{C}$, a 4 -h holding period at $-6.7 \mathrm{C}$, and a $1 \mathrm{C} / \mathrm{h}$ thaw to $5 \mathrm{C}$. Thawed seedlings were returned to a greenhouse and
Table 1. Freeze $\mathrm{e}^{\mathrm{z}}$ injury and leaf and stem survival of cold-acclimated potted seedlings that were grown from open-pollinated seed of 22 pummelo $x$ trifoliate orange hybrid citrus trees.

\begin{tabular}{|c|c|c|c|c|c|c|}
\hline \multirow[b]{3}{*}{$\begin{array}{l}\text { Tree } \\
\text { ID }^{y}\end{array}$} & \multirow[b]{3}{*}{$\begin{array}{l}\text { Seedlings } \\
\text { tested } \\
\text { (no.) }\end{array}$} & \multirow{2}{*}{\multicolumn{3}{|c|}{$\begin{array}{c}\text { Type of injury/ } \\
\text { seedling }(\%)\end{array}$}} & \multicolumn{2}{|c|}{$\begin{array}{l}\text { Extent of injury/ } \\
\text { seedling }\end{array}$} \\
\hline & & & & & \multirow{2}{*}{$\begin{array}{c}\text { Leaves } \\
\text { killed/ } \\
\text { seedling } \\
(\%)\end{array}$} & \multirow{2}{*}{$\begin{array}{c}\text { Stem } \\
\text { dieback/ } \\
\text { seedling } \\
(\%)\end{array}$} \\
\hline & & None & Leaf & $\begin{array}{c}\text { Leaf } \\
\text { and } \\
\text { stem }\end{array}$ & & \\
\hline $98-71^{x}$ & 68 & 97 & 3 & 0 & $6 \pm 4^{w}$ & 0 \\
\hline $98-88$ & 15 & 87 & 13 & 0 & $5 \pm 2$ & $3 \pm 1$ \\
\hline $98-43^{x}$ & 98 & 81 & 7 & 12 & $11 \pm 6$ & $3 \pm 2$ \\
\hline $98-53^{x}$ & 64 & 76 & 11 & 13 & $6 \pm 3$ & $1 \pm 1$ \\
\hline $98-45$ & 74 & 66 & 4 & 30 & $10 \pm 5$ & $5 \pm 2$ \\
\hline $98-62$ & 171 & 65 & 13 & 22 & $18 \pm 8$ & $8 \pm 3$ \\
\hline $98-74$ & 100 & 65 & 2 & 33 & $28 \pm 10$ & $20 \pm 8$ \\
\hline $98-70$ & 67 & 58 & 15 & 27 & $14 \pm 7$ & $9 \pm 5$ \\
\hline $98-69$ & 67 & 57 & 3 & 40 & $33 \pm 10$ & $24 \pm 8$ \\
\hline $98-61$ & 201 & 56 & 12 & 32 & $27 \pm 6$ & $18 \pm 5$ \\
\hline $98-85$ & 151 & 56 & 3 & 41 & $27 \pm 8$ & $15 \pm 5$ \\
\hline $98-39$ & 51 & 55 & 10 & 35 & $25 \pm 6$ & $10 \pm 5$ \\
\hline $98-59$ & 114 & 55 & 14 & 31 & $46 \pm 9$ & $17 \pm 11$ \\
\hline $98-73$ & 132 & 55 & 2 & 43 & $33 \pm 11$ & $24 \pm 8$ \\
\hline $98-79$ & 123 & 54 & 7 & 39 & $27 \pm 6$ & $18 \pm 4$ \\
\hline $98-84^{x}$ & 64 & 52 & 11 & 37 & $30 \pm 6$ & $15 \pm 4$ \\
\hline $98-67$ & 87 & 47 & 1 & 52 & $31 \pm 9$ & $25 \pm 8$ \\
\hline $98-68$ & 129 & 47 & 4 & 49 & $27 \pm 10$ & $13 \pm 7$ \\
\hline $98-80$ & 109 & 44 & 6 & 50 & $43 \pm 11$ & $32 \pm 9$ \\
\hline $98-72$ & 43 & 37 & 23 & 40 & $13 \pm 6$ & $2 \pm 1$ \\
\hline $98-54$ & 39 & 36 & 18 & 46 & $17 \pm 5$ & $4 \pm 2$ \\
\hline $98-83$ & 147 & 33 & 28 & 39 & $22 \pm 6$ & $2 \pm 1$ \\
\hline Total & 1950 & $59 \pm 15$ & $9 \pm 7$ & $32 \pm 14$ & -- & --- \\
\hline
\end{tabular}

${ }^{{ }^{2}}$ Listed in order of largest percentage of seedlings that had no visible damage during 5 weeks of postfreeze observations.

wMean $\pm S D$.

${ }^{x}$ Trees whose seed produced some presumed nucellar seedlings (based on leaf morphology) that were excluded from data in Table 2. 
Table 2. Morphological differences ${ }^{2}$ and freezey survival of cold-acclimated seedlings developed from seed of 22 pummelo $x$ trifoliate orange citrus hybrid trees.

\begin{tabular}{|c|c|c|c|c|c|c|c|}
\hline \multirow[b]{3}{*}{$\begin{array}{l}\text { Seed } \\
\text { origin }\end{array}$} & \multirow[b]{3}{*}{ Leaf shape } & \multirow[b]{3}{*}{$\begin{array}{c}\text { Seedling } \\
\text { tested } \\
\text { (no.) }\end{array}$} & \multirow{2}{*}{\multicolumn{3}{|c|}{$\begin{array}{c}\text { Type of injury/ } \\
\text { seedling }(\%)\end{array}$}} & \multicolumn{2}{|c|}{$\begin{array}{c}\text { Extent of injury/ } \\
\text { seedling }\end{array}$} \\
\hline & & & & & & \multirow{2}{*}{$\begin{array}{c}\text { Leaves } \\
\text { killed/ } \\
\text { seedlings } \\
(\%)\end{array}$} & \multirow{2}{*}{$\begin{array}{c}\text { Stem } \\
\text { dieback/ } \\
\text { seedlings } \\
(\%)\end{array}$} \\
\hline & & & None & Leaf & $\begin{array}{c}\text { Leaf } \\
\text { and } \\
\text { stem }\end{array}$ & & \\
\hline Nucellar & Trifoliate & 115 & 80 & 16 & 4 & $6 \pm 4^{x}$ & $1 \pm 1$ \\
\hline \multirow[t]{5}{*}{ Zygotic } & Trifoliate, small & 98 & 68 & 10 & 22 & $14 \pm 6$ & $6 \pm 6$ \\
\hline & Trifoliate, broad/round & 514 & 57 & 11 & 32 & $20 \pm 12$ & $11 \pm 8$ \\
\hline & Trifoliate, pointed & 1068 & 55 & 8 & 37 & $22 \pm 10$ & $12 \pm 8$ \\
\hline & Mixed (tri-, bi-, uni-) & 311 & 54 & 10 & 36 & $28 \pm 11$ & $19 \pm 6$ \\
\hline & Unifoliate & 82 & 54 & 19 & 27 & $24 \pm 12$ & $13 \pm 10$ \\
\hline
\end{tabular}

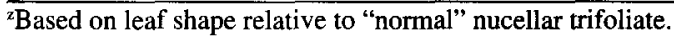

Freeze defined as $-6.7 \mathrm{C}$ for $4 \mathrm{~h}$.

Mean \pm sD.

rated for damage during 5 weeks of postfreeze observations. Trees were ranked from 1 to 22 based on the percentage of uninjured seedlings, and freeze damage was based on the percentage of leaves lost relative to the total number originally on a seedling and stem dieback relative to stem height above soil level. Statistical analyses, other than numerical ranking and listing comparison of means and standard deviations, were largely precluded because of nonreplication of seed lots. Means included all seedlings per tree seed lot, except nucellars, which were excluded in Table 1.

Results of freeze tests targeted tree 98-71 as the most likely candidate for inclusion in the
USDA citrus germplasm pool for genetic initiatives in citrus freeze survival (Table 1). More seedlings (97\%) from tree 98-71 were uninjured during $4 \mathrm{~h}$ of $-6.7 \mathrm{C}$ than any of the other 21 trees included in this study (ranging from $33 \%$ to $87 \%$ uninjured). Citrus $\times$ Poncirus hybrids are noted for their multifoliate leaf expressions, and a relatively low percentage of unifoliate progeny are characteristic from open-pollinated highly zygotic trifoliate orange hybrids (Cameron and Soost, 1980). Trifoliate, unifoliate, and a mix of all three foliate types segregated as expected. The impact of environment, known to influence leaf type, was not discernible in our screening results.
There were no indications that morphological differences were associated with the high rate of freeze survival (Table 2). None of the five morphological groups classified in this study was associated with increased freeze survival over presumed nucellar seedlings, which were $7 \%$ of the 98-71 population. Progeny of 98-71 are candidates for the USDA citrus rootstock/ scion development program (C.J. Hearn and K.D. Bowman, personal communication). This program progressively moves research material from germplasm acquisition through various horticultural evaluations leading to commercial citrus releases and includes germplasm evaluation for genetic transformation of desired traits. Comparison tests with commercial rootstock remain to be done.

\section{Literature Cited}

Barrett, H.C. and A.M. Rhodes. 1976. A numerical taxonomic study of affinity relationships in cultivated Citrus and its close relatives. Systematic Bot. 1:105-136.

Cameron, J.W. and R.K. Soost. 1974. Evidence for hybrid vigor in $F_{1}$ citrus populations with pummelo [Citrus grandis (L.) Osbeck] as one parent. J. Amer. Soc. Hort. Sci. 99:433-435.

Cameron, J.W. and R.K. Soost. 1980. Leaf types of $F_{1}$ hybrids and backcrosses involving unifoliolate Citrus and trifoliolate Poncirus. J. Amer. Soc. Hort. Sci. 105:517-519.

Yelenosky, G. 1979. Accumulation of free proline in citrus leaves during cold hardening of young trees in controlled temperature regimes. Plant Physiol. 64:425-427. 